\section{高温電極による原子炉中の 腐食モニタリング}

\section{藤 井 哲 雄*}

軽水炉, 発電ボイラ, 化学プラントなどの高温高圧水 溶液環境における腐食試験はオートクレーブや腐食試験 ループ中に試験片を一定期間浸漬し, 試験前後の重量変 化あるいは割れの有無の検出を行らのが常套手段であっ た。そして腐食試験期間中は何ら手段をほどこすことな く，ひたすら時間の経過を待つのみであった。もし,直接 高温高圧下に打いて腐食に関する熱力学的または速度論 的な情報が兄られれば原因の究明や腐食機構を考光る上 で手がかりが兄れるはずである。ところで,われわれは 常温の水溶液中に打㤝金属の腐食現象や不動態化現象 に対して電気化学が有力な研究手段で制ることを知って おり，すでに多くの知識と経験を積んできた。しかし，常 温のデータを軽水炉環境である $573 \mathrm{~K}\left(300^{\circ} \mathrm{C}\right)$ の水に外 挿するにはあまりに条件が異なっているため，高温高圧 の実環境に近い条件下での実測が必要となる。このよう な観点から 1960 年代に入って高温高压水溶液中の電気 化学測定に関する研究が始められるようになった，1973 年，イギリスのSurrey 大学に沶いて開催された「高温 高圧水溶液中の電気化学」に関する国際会議(1)では地球 化学, 燃料電池, 湿式治金などを含めた高温高圧技術に ついてこれまでの成果や情報が整理された。この会議を 契機として次第に活発な研究が行われるようになった。

近年, 沸騰水型原子炉 (BWR) に抢けるステンレス鋼配 管溶接部の粒界応力腐食割れ事故は安全にかかわる問題 とはなっていないが，原子炉の経済性の面から緊急に解 決を要する問題として原因の究明や防止対策が精力的に 進められている。加圧水型原子炉 $(\mathrm{PWR})$ に执いては蒸気 発生器のインコネル 600 配管の減肉腐食や応力腐食割れ 事例が報告され,減肉腐食は水处理をりン酸塩処理から揮 発性物質を用いるボラタイル処理に変更されてからこの 種の腐食はなくなったといわれている。軽水炬における このよらな応力腐食割れ問題を解決するためには材料, 応力，環境などの面から検討されなければならないが， 環境側因子を究明するために高温高圧水環境下での電気 化学測定が導入され，試料の電位を規制した条件下で応

* 金属材料技術研究所腐食防食研究部第 4 研究室室 長 1977 年11月 9 日受理

日本金属学会会報第 17 巻第 1 号 (1978)
力腐食割れ試験が行われるようになった。その結果，応 力腐食割れが特定の電位域で起る事実がいくつか報告さ れるに至っている，ステンレス鋼の自然電位が水中溶存 酸素濃度によって大きく変化しらることから, 水の照射 分解によって子酸素を生成する BWR では実原子炉内で のステンレス鋼の自然電位や溶液の酸化還元電位がどの ような值にあるか実測することの重要性が認識されるよ らになった，BWR での最初の電位測定の試みは 1968〜 1969 年に G. E. の Cowan ら ${ }^{(1)}$ よって Vermont Yankee のDresden I-BWR を用いて行われ，2 次 蒸気発生器入口部に扔いて Pt 拈上び 304 ステンレス鋼 の自然電位がモニターされた。しかし，このときは照合 電極 (基潐電極)としての塩化銀電極がかならずしも満足 飞作動しなかったよらである。その後，灯外試験におい て塩化銀電極の構造上の改良が加光られ，1975～1976

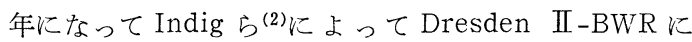
おいて行われた。すなわち，図１亿示すごとく再循環配 管系のバイパス管端部に塩化銀電極，Pt，打よび 304 ス テンレス鋼試片を備えたフランジを取付け，原子炬の定 常運転時, 起動拉よび停止時飞括ける電位変化がモ二 ターされた。電位測定と同時に温度測定孔を通して炉皮 の, $\mathrm{pH}$, 溶存酸素, 過酸化水素濃度の分析が行われた， その結果，Pt 拈よび 304 ステンレス鋼の電位変化と溶 存酸素捛よび過酸化水素濃度の変化との間に明暸な対応 関係が認められた。一般に炉水の温度が上昇するにつれ 溶存酸素濃度は減じ，ステンレス鋼拈よび Pt の電位は 低下し, 定常状態では $-0.15 \sim-0.13 \mathrm{~V}$ (SHE, $549 \mathrm{~K}$ ) に達した。 また，非定常運転時には $+0.1 \mathrm{~V}$ と高い電位 も記録されている。これは邩外試験の結果によると鋭 敏化した 304 ステンレス鋼が応力腐食割れを起しらる電 位である。これまで原子师でえられた情報はわずかであ

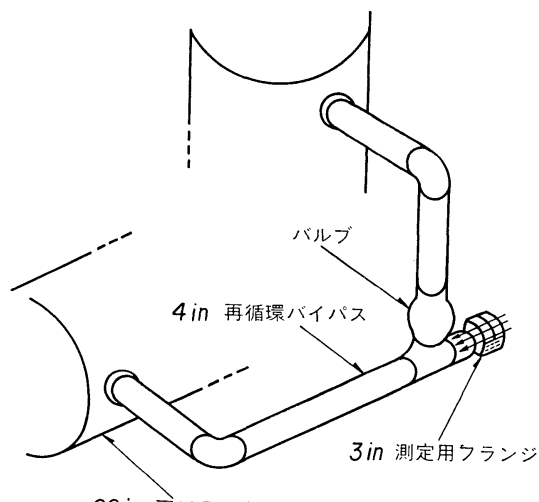

26 in 再循環配管

図 1 再循環拉よびバイパス配管(2). 
るが応力腐食割れ試験条件を設定する上で実原子炬で 自然電位や溶液の酸化還元電位の実測を可能にした意義 は大きい，原子炉でえられたこれらの実測データの解析 は炉外での高温高圧水溶液中の電気化学測定デー夕に照 してはじめて可能になる。この意味から炉外の高温高压 水中に拉ける電気化測定データの蓄積が望まれる。今日 まで高温高圧水溶液中の電気化学測定は著しい進歩があ ったものの，まだ確立された方法とはなっていない。ガ ラスセルを用いる常温大気圧下に比べて $573 \mathrm{~K}, 10.13$ $\mathrm{MPa}$ (100 気压) の高温高圧容器内での電気化学測定は 実験技術上，いろいろ困難な問題がある。最も基本的な 問題は照合電極をどうするかという点にある。照合電極 の設置方法 ${ }^{(3)} に は 二$ 通りあり, 一つは照合電極を試験液 と同じ温度圧力に保持する方法で内部電極法と呼んでい る。もら一つの方法は照合電極を高温高圧系外の室温大 気圧下に保持し高温高压容器内と圧カシールを介して連 液する方法で外部電極法と呼んでいる。両者はそれぞれ 得失を有するが，実原子炉適用する場合は水が压力容 器内から少しずつにじみ出す構造の外部電極法は好まし くない.内部電極法は照合電極が高温の水にさらされる ので高温特性が明らかで，しかも安定な電極であること が必要である。それらの点を考虑すると現在のところ塩 化銀電極が最も期待されるものであり，これまでにいる いろな構造のものが提案されている.塩化銀電極の内部 液 $\left(0.01 \sim 0.1 \mathrm{k} \mathrm{mol} / \mathrm{m}^{3} \mathrm{KCl}\right.$ 溶液)によって試験液が污 染されることなく, 連液が保証された構造のものが要求 される.図2はこうした塩化銀電極の一例として最近 Magar と Morris ${ }^{(4)}$ にって発表された電極の構造を 示す.テフロン円筒内に塩化銀電極素子が内部液ととも に收納されて拉りアスベスト心を通して外部夜と液が連

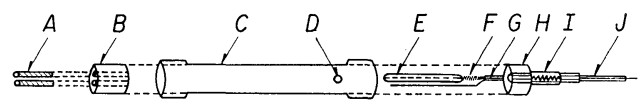

A：熱収縮性テフロソに包んだアスベスト心, $\mathrm{B}$ ：液絡用テフロンマウント， C : テフロン チューブ, D : 孔, $E$ : 塩化銀電極素子, $\mathrm{F}$ : 銀線, $\mathrm{G}$ : テフロン銀線, $\mathrm{H}$ : テフロン キャップ, I : 熱収縮性テフロン, J : リー ド線

図 2 高温用塩化銀電極の一例 ${ }^{(4)}$.
絡する構造になっている，塩化銀電極も $\mathrm{H}_{2}$ が存在する PWR 1 次系の環境では溶解しやすく使用できないとも いわれ，このような PWR 環境で使用できる電極の開発 も望まれて扣り, $\mathrm{Ni}$ 電極や $\mathrm{Pd}$ 水素化物電極が提案さ れている。いずれにしても高温高圧下の電気化学測定の 普及は照合電極の開発に待つ点が大きい，上述したよう な電位測定を主体とした環境モニタリングに対して, 電 流 一電位曲線を測定して腐食速度などの速度論的な情報 を光よらとする努力も行われている。しかし，BWR のような希薄水溶液では導電率が低いことによるIR 降 下の影響を除去しなければならないなど困難な問題が多 く, 目下は中性塩を添加し導電率を高めた昵外環境で分 極曲線の測定が試みられている。一方，アルカリなどの 濃縮による局部腐食が問題となる PWR 環境では分極抵 抗法の適用による腐食速度のモニタリングが期待され る.

今後の問題としては現実の差し迫った問題となってい る応力腐食割れや局部腐食の問題に対応して, ともかく 電位測定を行いたいとする性急な要求のあまり照合電極 自体の特性, 溶液化学, 拉上び電気化学の基礎的な検討 が不足しているように思われる。先頃, アメリカで開催 されたEPRI(Electric Power Research Institute) 主催の高温水電気化学に関するミーティングにおいても 短期的には照合電極の開発を急がなければならないが, 長期的には高温水電気化学のデータの基礎を与える熱力 学的な研究の重要性が指摘された。このような発展に よって将来, 原子炬環境ばかりでなく, 高温高圧水をと り扱らいろいろな分野での腐食モニタリングの適用も可 能になるものと考兄られる。

\section{文献}

(1) Proc. of International Conference on High Temperature High Pressure Electrochemistry in Aqueous Solutions, Ed.by R.W. Staehle and D.de G.Jones, Published by NACE., (1976)

(2) M.E.Indig, J.E.Weber and A.D.Miller : Paper No.151, NACE Annual Conference, San Francisco, (1977).

（3）藤井哲雄：防食技術，23(1974)，257.

(4) I.J.Magar and P.E.Morris: Corrosion, 32 (1976), 374.? 